\title{
KEMAMPUAN BERPIKIR TINGKAT TINGGI SISWA KELAS XI PMIA MAN TANJUNG MORAWA PADA PEMBELAJARAN SEL DENGAN MODEL PBL BERBANTUAN LKS
}

\section{HIGH ORDER THINKING SKILL STUDENT CLASS XI PMIA MAN TANJUNG MORAWA ON CELL LEARNING WITH LKS-ASSISTED PBL MODEL}

\author{
Windi Novia Sari ${ }^{*}$, Melva Silitonga \\ Program Studi Pendidikan Biologi, FMIPA, Universitas Negeri Medan \\ Jl. Williem Iskandar Psr. V Medan Estate, Medan, Indonesia, 20221 \\ *E-mail : windinovias@gmail.com
}

\begin{abstract}
ABSTRAK
Penelitian ini bertujuan untuk mendeskripsikan kemampuan berpikir tingkat tinggi siswa kelas XI PMIA MAN Tanjung Morawa pada pembelajaran sel dengan model PBL berbantuan LKS. Penelitian ini termasuk jenis pre-eksperimen dengan desain one group pretest posttest dan dilaksanakan dalam empat kali pertemuan. Instrumen penelitian yang digunakan adalah tes pilihan ganda sebanyak 25 soal. Data yang diperoleh dari penelitian ini meliputi nilai kemampuan berpikir tingkat tinggi siswa baik secara umum maupun pada setiap aspeknya. Data yang diperoleh dianalisis untuk mendapatkan nilai rata- rata. Hasil analisis data menunjukkan bahwa rata- rata nilai kemampuan berpikir tingkat tinggi siswa secara umum tergolong baik yaitu 78,4 . Nilai rata- rata siswa pada aspek menganalisis dengan kategori sangat baik $(82,1)$, mengevaluasi dengan kategori baik $(73,0)$ dan mengkreasi dengan kategori baik $(78,6)$. Berdasarkan hasil penelitian, model pembelajaran PBL berbantuan LKS sangat tepat digunakan dalam melatih kemampuan berpikir tingkat tinggi siswa kelas XI di MAN Tanjung Morawa pada pembelajaran biologi materi sel.

Kata Kunci : kemampuan berpikir tingkat tinggi, model PBL berbantuan LKS
\end{abstract}

\section{ABSTRACT}

This study aims to describe high order thinking skills students of class XI PMIA MAN Tanjung Morawa on cell learning with LKS assisted model PBL. This study included pre-experiment type with one group pretest posttest design and was conducted in four meetings. The research instrument used is a multiple choice test of 25 questions. Data obtained from this study include the value of students' high order thinking skill both in general and in every aspect. The data obtained were analyzed to obtain the average value. The result of data analysis shows that the average of students' high order thinking skill is generally good, that is 78,4 . The average score of the students on the aspect of analyzing with the category was very good (82.1), evaluating with good category $(73,0)$ and creating with good category $(78,6)$. Based on the results of the research, the LKS-assisted PBL learning model is very aptly used in training the high-class thinking ability of the class XI students at MAN Tanjung Morawa on the study of biology cell.

Keyword : high order thinking skill, model PBL assisted student worksheet

\section{PENDAHULUAN}

Kemampuan berpikir tingkat tinggi merupakan kemampuan menghubungkan, memanipulasi, dan mentransformasi pengetahuan serta pengalaman yang sudah dimiliki untuk berpikir secara kritis dan kreatif dalam upaya menentukan keputusan dan memecahkan masalah pada situasi baru. Kemampuan berpikir tingkat tinggi meliputi kemampuan analisis, evaluasi dan kreasi (Rofiah, $d k$. 2013). Kemampuan berpikir tingkat tinggi merupakan aspek yang sangat penting dalam proses belajar mengajar. Kemampuan berpikir tingkat tinggi berpengaruh terhadap kemampuan siswa dalam belajar dan efektivitas pembelajaran sehingga tujuan pembelajaran dapat dicapai. Penelitian yang dilakukan oleh Heong, dkk (2011) mengatakan bahwa kemampuan berpikir tingkat tinggi memiliki pengaruh yang positif dalam mengembangkan kemampuan siswa dalam menyelesaikan permasalahan.

Kemampuan berpikir tingkat tinggi (Higher Order Thinking) siswa saat ini semakin dibutuhkan, karena melalui cara berpikir seperti ini akan dapat diterapkan dalam memecahkan masalah dalam kehidupan nyata. Banyak persoalan yang akan dan bahkan selalu ditemukan siswa dalam kehidupan sehari-harinya, maka dibutuhkan kemampuan berpikir untuk mengatasi persoalan-persoalan tersebut (Hasruddin, $d k k$. 2016).

Oleh karena pentingnya kemampuan berpikir tingkat tinggi bagi siswa, maka diperlukan model pembelajaran yang tepat untuk melatih siswa dalam berpikir tingkat tinggi. Model PBL merupakan salah satu model pembelajaran yang dapat meningkatkan kemampuan berpikir tingkat tinggi siswa. Penelitian Putriyani (2014) menyatakan bahwa terjadi 
peningkatan kemampuan berpikir tingkat tinggi siswa yang diajarkan dengan model PBL sebesar 71\% dalam kategori sedang. Pembelajaran dengan model PBL menuntun siswa dalam mengidentifikasi masalah dan mencari solusi berdasarkan literatur maupun melalui percobaan sehingga dapat melatih kemampuan berpikir tingkat tinggi (Susanti, $d k$ k. 2015).

Model PBL merupakan model pembelajaran yang inovatif yang melatih siswa untuk mampu menghubungkan pengetahuan yang mereka pelajari dan bagaimana pengetahuan tersebut akan dimanfaatkan atau diaplikasikan pada situasi baru sehingga pengetahuan yang didapat bermakna bagi kehidupan (Trianto, 2009).

Dalam pembelajaran dengan menggunakan model PBL, siswa dituntun untuk menganalisis permasalahan menjadi pokok- pokok masalah, kemudian melakukan evaluasi terhadap langkahlangkah pemecahan masalah dan merancang produk yang dapat membantu siswa untuk mengkomunikasikan hasil pemecahan masalah.

Model Problem Based Learning menekankan keterampilan dalam memecahkan masalah, menyelidiki masalah dan menemukan solusi dari permasalahan tersebut. Dalam pembelajaran, siswa terlibat secara aktif memecahkan permasalahan yang ada melalui beberapa tahapan diantaranya membangun kerangka masalah, mencermati, mengumpulkan data dan menyusun argumentasi terkait pemecahan masalah tersebut. Kemudian membuat laporan maupun produk yang dipresentasikan sehingga dapat mewakili solusi yang terpilih (Arends, 2008).

Agar pembelajaran dengan model PBL dapat berlangsung dengan efektif diperlukan media pembelajaran yang dapat meningkatkan kemampuan berpikir tingkat tinggi. Salah satu media pembelajaran yang dapat digunakan adalah lembar kerja siswa (LKS). Penggunaan LKS dapat mendorong siswa untuk terlibat aktif dalam memecahkan masalah. Selain itu, penggunaan LKS dalam pembelajaran dapat mendorong siswa untuk mencari, mengerjakan dan memahami pelajaran (Suryana dan Melva, 2017). Dengan penerapan LKS siswa dituntun untuk mampu mencari solusi dari permasalahan karena pada LKS terdapat langkahlangkah pemecahan masalah secara sistematis sehingga dapat melatih kemampuan berpikir tingkat tinggi siswa.

Penerapan model PBL berbantuan LKS dalam proses pembelajaran, siswa dituntun untuk dapat melakukan analisis masalah dengan cara menguraikan pokok- pokok permasalahan. Kemudian siswa dituntun untuk melakukan evaluasi apakah data yang dikumpulkan dapat menjawab permasalahan atau tidak. Untuk memaparkan hasil dari pemecahan masalah, siswa dituntun untuk membuat laporan tertulis yang akan dikomunikasikan dalam forum diskusi.

Berdasarkan uraian di atas, perlu dilakukan penelitian untuk proses pembelajaran yang dapat melatih kemampuan berpikir tingkat tinggi siswa dengan judul "Kemampuan Berpikir Tingkat Tinggi Siswa Kelas XI PMIA MAN Tanjung Morawa Pada Pembelajaran Sel dengan Model PBL berbantuan LKS".

\section{METODE PENELITIAN}

Penelitian ini dilakukan di kelas XI PMIA 1 MAN Tanjung Morawa dengan jumlah siswa sebanyak 35 orang. Pembelajaran dilakukan sebanyak empat kali pertemuan. Penelitian dilakukan mengacu pada langkah- langkah pembelajaran dengan model PBL berbantuan LKS yaitu memberikan orientasi tentang permasalahan yang berkaitan dengan proses yang berlangsung pada sel, mengorganisasi siswa untuk belajar dengan cara menjelaskan kepada siswa mengenai tugas- tugas dan topik yang harus didiskusikan, membantu penyelidikan yaitu dengan cara menelusuri literatur dan melakukan praktikum untuk menjawab permasalahan, mengembangkan dan menyajikan hasil karya berupa laporan diskusi maupun laporan hasil praktikum serta menganalisis atau mengevaluasi proses mengatasi masalah. Kemudian diberikan tes pada akhir pembelajaran untuk mengetahui kemampuan berpikir tingkat tinggi siswa.

Instrumen tes tertulis sebanyak 25 soal digunakan untuk memperoleh data kemampuan berpikir tingkat tinggi siswa kelas XI PMIA 1 MAN Tanjung Morawa. Soal disusun berdasarkan aspek kemampuan berpikir tingkat tinggi yaitu analisis (C4), evaluasi (C5) dan kreasi (C6).

Teknik analisis data pada penelitian ini adalah nilai kemampuan berpikir tingkat tinggi secara umum dan nilai kemampuan berpikir tingkat tinggi pada setiap aspek. Hasil tes dinilai berdasarkan pedoman penskoran, jika benar diberi skor 1 dan salah diberi skor 0 . Perhitungan untuk memperoleh nilai yaitu skor yang diperoleh siswa dikali seratus kemudian dibagi skor maksimal.

\section{HASIL PENELITIAN}

Kemampuan berpikir tingkat tinggi terdiri atas tiga aspek yaitu menganalisis (C4), mengevaluasi (C5) dan mengkreasi (C6). Nilai kemampuan berpikir tingkat tinggi siswa kelas XI PMIA 1 MAN Tanjung Morawa pada setiap aspek dilihat pada Tabel 1. 
Tabel 1. Nilai kemampuan berpikir tingkat tinggi pada setiap aspek

\begin{tabular}{ccc}
\hline Aspek & Nilai Siswa & Kategori \\
\hline Menganalisis (C4) & 82,1 & Sangat baik \\
\hline Mengevaluasi (C5) & 73,0 & Baik \\
\hline Mengkreasi (C6) & 78,6 & Baik \\
\hline
\end{tabular}

Pada Tabel 1. dapat dilihat bahwa aspek menganalisis siswa dalam kategori sangat baik. Dalam pembelajaran dengan menggunakan model $\mathrm{PBL}$, diajukan permasalahan yang harus diselesaikan oleh siswa. Sebagian besar siswa mampu menganalisis masalah dengan cara merinci pokokpokok permasalahan kemudian menyimpulkan permasalahan tersebut menjadi rumusan masalah dalam bentuk kalimat tanya.

Tabel 2. Nilai Kemampuan berpikir tingkat tinggi siswa pada materi Sel

\begin{tabular}{cccc}
\hline Nilai & Kategori & Frekuensi & Persentase \\
\hline $81-100$ & Sangat Baik & 12 & 34,28 \\
$61-80$ & Baik & 20 & 57,14 \\
$41-60$ & Cukup & 2 & 5,7 \\
$21-40$ & Kurang & 1 & 2,85 \\
$0-20$ & Sangat Kurang & 0 & 0 \\
\hline \multicolumn{4}{c}{ Rata- rata nilai }
\end{tabular}

\section{PEMBAHASAN}

Dalam pembelajaran menggunakan model PBL diajukan permasalahan sehingga siswa dituntun untuk menganalisis masalah tersebut. Kemudian siswa dituntun untuk mengevaluasi atau menyelesaikan masalah dan mengembangkannya dalam bentuk presentasi berupa laporan yang melatih siswa dalam aspek kreasi.

Aspek menganalisis (C4) memperoleh nilai tertinggi karena pembelajaran menggunakan model PBL berbantuan LKS berfokus pada penyelidikan terhadap masalah yang diajukan. Agar pemecahan masalah berjalan dengan baik, maka siswa dituntun untuk membagi- bagi atau menguraikan masalah tersebut dalam bentuk pokok- pokok permasalahan. Dalam menguraikan masalah maka diperlukan kemampuan analisis, sehingga mayoritas siswa telah terbiasa dalam menganalisis masalah.

Aspek mengevaluasi (C5) memperoleh nilai dalam kategori baik disebabkan karena dalam penerapan model PBL berbantuan LKS, masalah yang telah diuraikan dan dirumuskan akan dicari penyelesaiannya. Untuk mencari penyelesaian masalah, siswa dituntun untuk melakukan evaluasi dengan cara memprediksi penyebab terjadinya masalah tersebut dan langkah- langkah penyelesaian masalah. Selain itu, dalam pembelajaran diajukan sebuah pernyataan yang harus dinilai kebenarannya oleh siswa berdasarkan penelusuran baik melalui literatur maupun datadata yang diperoleh dari praktikum. Sehingga siswa dituntun untuk menolak maupun menerima kebenaran suatu teori berdasarkan fakta- fakta yang ada.

Nilai aspek mengevaluasi lebih rendah daripada nilai aspek menganalisis karena tidak semua siswa dapat memutuskan, menilai, mendukung maupun menolak serta memprediksi permasalahan dengan tepat. Berdasarkan pengamatan di lapangan, sebagian siswa masih kesulitan dalam merumuskan prediksi atau hipotesis dengan baik yaitu dengan kriteria hipotesis yang dirumuskan kurang lengkap dan tidak mengandung semua variabel. Sebagian siswa juga mengalami kesulitan dalam menilai benar tidaknya suatu pernyataan berdasarkan fakta- fakta yang ditemukan.

Aspek mengkreasi (C6) memperoleh nilai dengan kategori baik karena dalam penerapan model PBL berbantuan LKS, siswa dituntun untuk merancang tahapan penyelesaian masalah dan mengembangkan hasil karya dalam bentuk laporan hasil diskusi mengenai penyelesaian masalah yang dilakukan. Setiap tahap penyelesaian masalah yang dirancang dipresentasikan dalam bentuk laporan yang memudahkan siswa dalam menjelaskan pemecahan masalah di depan kelas.

Aspek mengkreasi memperoleh nilai yang lebih rendah dibandingkan analisis. Hal tersebut karena tidak semua siswa mampu menyusun laporan dengan baik dan sistematis. Sebagaimana penelitian yang dilakukan oleh Prasetyani, $d k k$ (2016) yang menyatakan bahwa aspek menganalisis yang memiliki nilai tertinggi dibandingkan dengan 
mengevaluasi dan mengkreasi karena menganalisis merupakan tingkat kemampuan terendah dari kemampuan bepikir tingkat tinggi sehingga lebih banyak siswa yang berhasil pada indikator tersebut dibandingkan indikator berpikir tingkat tinggi lainnya. Nilai kemampuan berpikir tingkat tinggi siswa kelas XI PMIA 1 MAN Tanjung Morawa dapat dilihat pada Tabel 2.

Pada Tabel 2. dapat dilihat bahwa kemampuan berpikir tingkat tinggi siswa kelas $\mathrm{XI}$ PMIA 1 MAN Tanjung Morawa sebesar 78,4 dengan kategori baik. Sebanyak 91,42\% siswa memiliki kemampuan berpikir tingkat tinggi dalam kategori sangat baik dan baik. Hanya 2 orang siswa yang memiliki nilai kemampuan berpikir tingkat tinggi dalam kategori cukup dan tidak seorangpun siswa yang memiliki kemampuan berpikir tingkat tinggi dalam kategori sangat kurang.

Siswa dapat memperoleh nilai dalam kategori baik disebabkan karena penerapan model PBL dalam proses pembelajaran diajukan sebuah permasalahan yang harus dianalisis oleh siswa sehingga permasalahan dapat terselesaikan dengan baik.

Nilai kemampuan berpikir tingkat tinggi yang baik terjadi karena dalam penggunaan model PBL berbantuan LKS, siswa dituntun untuk dapat menyelesaikan permasalahan dalam kategori tingkat tinggi yaitu menganalisis, mengevaluasi dan mengkreasi. Dalam proses belajar mengajar menggunakan model PBL berbantuan LKS diajukan permasalahan yang erat kaitannya dengan kehidupan. Masalah tersebut harus diuraikan oleh siswa menjadi pokok- pokok masalah agar lebih mudah untuk dicari penyelesaiannya.

Pokok permasalahan kemudian dianalisis dan dirumuskan dalam bentuk rumusan masalah. Selanjutnya siswa dilatih untuk mampu mengevaluasi masalah yaitu dengan cara merumuskan prediksi atau hipotesis yang dapat menjawab rumusan masalah. Kemudian dalam proses penyelesaian masalah, siswa dilatih untuk merancang penyelesaian masalah dengan cara mengumpulkan data yang berkaitan dengan masalah tersebut dan data- data tersebut harus diterjemahkan dan dihubungkan dengan teoriteori. Setiap tahapan penyelesaian masalah tersebut dapat melatih siswa agar mampu berpikir tingkat tinggi, sehingga model PBL berbantuan LKS berkontribusi terhadap kemampuan berpikir tingkat tinggi.

Sebagaimana penelitian Putriyani (2014) menunjukkan bahwa rata- rata nilai kemampuan berpikir tingkat tinggi siswa yang diajarkan dengan model PBL sebesar 78,00 (baik). Dengan penerapan model PBL berbantuan LKS, siswa dituntun untuk menganalisis masalah dengan cara menguraikan permasalahan kemudian memilih solusi yang tepat untuk menjawab permasalahan. Siswa juga dituntun untuk merancang hasil karya yang dapat membantunya untuk mengkomunikasikan hasil pemecahan masalah.

\section{KESIMPULAN}

Berdasarkan hasil penelitian di kelas XI PMIA MAN Tanjung Morawa, diperoleh hasil bahwa kemampuan berpikir tingkat tinggi siswa pada pembelajaran biologi materi sel dalam kategori baik yaitu 78,4 . Nilai kemampuan berpikir tingkat tinggi siswa pada aspek analisis 82,1 (sangat baik), evaluasi 73,0 (baik) dan kreasi 78,6 (baik). Dengan demikian dapat dinyatakan bahwa model PBL berbantuan LKS pada materi sel dapat melatih kemampuan berpikir tingkat tinggi siswa.

\section{UCAPAN TERIMA KASIH}

Terima kasih terkhusus kepada Ibu Tri Ade, S.Pd., M.Pd. selaku guru bidang studi Biologi serta seluruh siswa kelas XI PMIA 1 yang telah banyak membantu selama penelitian.

\section{DAFTAR PUSTAKA}

Arends, R.I., (2008), Belajar Untuk Mengajar, Pustaka Pelajar, Yogyakarta.

Hasruddin, Harahap, F., dan Mahmud, (2016), Pengembangan Perangkat Pembelajaran Mikrobiologi berbasis Kontekstuak untuk Meningkatkan Kemampuan Berpikir Tingkat Tinggi, Proceeding Biology Education Conference 13: 509-514

Heong, Y.M., Widad, Jailani, Razali, T., dan Mohaffyza, M., (2011), The Level of Marzano Higher Order Thinking Skills among Technical Education Students, International Journal of Science and Humanity 1: 121-125

Prasetyani E., Hartono, Y., Susanti, E., (2016), Kemampuan Berpikir Tingkat Tinggi Siswa Kelas XI dalam Pembelajaran Trigonometri Berbasis Masalah di SMA Negeri 18 Palembang, Jurnal Gantang Pendidikan Matematika FKIP-UMRAH 1: 31- 40

Putriyani, (2014), Penggunaan LKS berbasis Problem Based Instruction untuk Meningkatkan Keterampilan Berpikir Tingkat Tinggi Siswa pada Konsep Jamur, Skripsi, Fakultas IImu Tarbiyah dan Keguruan, UIN Syarif Hidayatullah, Jakarta.

Rofiah,E., Aminah,N.S., dan Ekawati,E.Y., (2013), Penyusunan Instrumen Tes Kemampuan 
Halaman : 361 - 365

Berpikir Tingkat Tinggi Fisika pada Siswa SMP, Jurnal Pendidikan Fisika 1: 17-22

Suryana, E. Dan Melva, S., (2017), Implementasi Pembelajaran Berbasis Lembar Kerja Siswa (LKS) dengan Pendekatan Saintifik pada Pembelajaran Biologi di SMA Negeri 5 Medan, Jurnal Pelita Pendidikan 5: 52-57

Susanti, A.T., Prayitno,B.A., dan Sudarisman,S., (2015), Pengaruh Model Problem Based Learninng Disertai Media Key Relation Chart terhadap Kemampuan Berpikir Kritis dan Kerjasama Siswa dalam Kelompok pada Kelas VIII SMP Negeri 14 Surakarta Tahun Pembelajaran 2012/2013, Jurnal Pendidikan Biologi 7: 1-13

Trianto, (2009), Mendesain Model Pembelajaran Inovatif- Progresif, Kencana, Jakarta. 